\title{
Front Matter: Volume 7187
}

, "Front Matter: Volume 7187," Proc. SPIE 7187, Biomedical Applications of Light Scattering III, 718701 (20 March 2009); doi: 10.1117/12.822791

SPIE. Event: SPIE BiOS, 2009, San Jose, California, United States 


\section{PROGRESS IN BIOMEDICAL OPTICS AND IMAGING}

Vol. 10, No. 27

\section{Biomedical Applications \\ of Light Scattering III}

Adam Wax

Vadim Backman

Editors

24-26 January 2009

San Jose, California, United States

Sponsored and Published by

SPIE

Volume 7187

Proceedings of SPIE, 1605-7422, v. 7187

SPIE is an international society advancing an interdisciplinary approach to the science and application of light. 
The papers included in this volume were part of the technical conference cited on the cover and title page. Papers were selected and subject to review by the editors and conference program committee. Some conference presentations may not be available for publication. The papers published in these proceedings reflect the work and thoughts of the authors and are published herein as submitted. The publisher is not responsible for the validity of the information or for any outcomes resulting from reliance thereon.

Please use the following format to cite material from this book:

Author(s), "Title of Paper," in Biomedical Applications of Light Scattering III, edited by Adam Wax, Vadim Backman, Proceedings of SPIE Vol. 7187 (SPIE, Bellingham, WA, 2009) Article CID Number.

ISSN $1605-7422$

ISBN 9780819474339

Published by

SPIE

P.O. Box 10, Bellingham, Washington 98227-0010 USA

Telephone +1 3606763290 (Pacific Time) · Fax +1 3606471445

SPIE.org

Copyright @ 2009, Society of Photo-Optical Instrumentation Engineers.

Copying of material in this book for internal or personal use, or for the internal or personal use of specific clients, beyond the fair use provisions granted by the U.S. Copyright Law is authorized by SPIE subject to payment of copying fees. The Transactional Reporting Service base fee for this volume is $\$ 18.00$ per article (or portion thereof), which should be paid directly to the Copyright Clearance Center (CCC), 222 Rosewood Drive, Danvers, MA 01923. Payment may also be made electronically through CCC Online at copyright.com. Other copying for republication, resale, advertising or promotion, or any form of systematic or multiple reproduction of any material in this book is prohibited except with permission in writing from the publisher. The CCC fee code is 1605$7422 / 09 / \$ 18.00$.

Printed in the United States of America.

Publication of record for individual papers is online in the SPIE Digital Library.

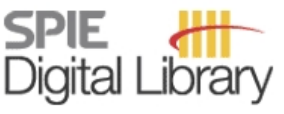

SPIEDigitalLibrary.org

Paper Numbering: Proceedings of SPIE follow an e-First publication model, with papers published first online and then in print and on CD-ROM. Papers are published as they are submitted and meet publication criteria. A unique, consistent, permanent citation identifier (CID) number is assigned to each article at the time of the first publication. Utilization of CIDs allows articles to be fully citable as soon they are published online, and connects the same identifier to all online, print, and electronic versions of the publication. SPIE uses a six-digit CID article numbering system in which:

- The first four digits correspond to the SPIE volume number.

- The last two digits indicate publication order within the volume using a Base 36 numbering system employing both numerals and letters. These two-number sets start with 00, 01, 02, 03, 04 , $05,06,07,08,09,0 A, 0 B \ldots 0 Z$, followed by 10-1Z, 20-2Z, etc.

The CID number appears on each page of the manuscript. The complete citation is used on the first page, and an abbreviated version on subsequent pages. Numbers in the index correspond to the last two digits of the six-digit CID number. 


\section{Contents}

vii Conference Committee

\section{TISSUE PHANTOM STUDIES}

718702 Diffuse optical spectroscopy of melanoma-simulating silicone phantoms [7187-01] A. M. Grant, K. Sry, R. Saager, F. Ayers, Univ. of California, Irvine (United States); T. J. Pfefer, U.S. Food and Drug Administration (United States); K. M. Kelly, S.-H. Tseng, A. J. Durkin, Univ. of California, Irvine (United States)

\section{TURBIDITY SUPPRESSION}

718707 Revisiting optical clearing with dimethyl sulfoxide (DMSO): in vitro and in vivo studies [7187-06]

R. A. McClure, C. Stoianovici, S. Karma, B. Choi, Univ. of California, Irvine (United States)

\section{DYNAMIC SCATTERING}

7187 OA Path length resolved optical Doppler flowmetry (Invited Paper) [7187-09]

B. Varghese, V. Rajan, Univ. Twente (Netherlands); T. G. Van Leeuwen, , Univ. Twente (Netherlands) and Laser Ctr. (Netherlands); W. Steenbergen, Univ. Twente (Netherlands)

NUMERICAL SIMULATION STUDIES

7187 OG Monte Carlo propagation of spatial coherence (Invited Paper) [7187-15]

S. A. Prahl, Providence St. Vincent Medical Ctr. (United States) and Oregon Health \& Science Univ. (United States); D. D. Duncan, Oregon Health \& Science Univ. (United States); D. G. Fischer, NASA Glenn Research Ctr. (United States)

$7187 \mathrm{OH}$ Mathematical modeling of reflectance and intrinsic fluorescence for cancer detection in human pancreatic tissue [7187-16]

R. H. Wilson, M. Chandra, J. Scheiman, D. Simeone, B. McKenna, J. Purdy, M.-A. Mycek, Univ. of Michigan (United States)

7187 Ol Three-dimensional computation of focused beam propagation through multiple biological cells [7187-17]

M. S. Starosta, A. K. Dunn, The Univ. of Texas at Austin (United States)

$71870 \mathrm{~J}$ Computational analysis of mitochondrial placement and aggregation effects on wide-angle cell scattering patterns [7187-18]

P. M. Pilarski, X.-T. Su, D. M. Glerum, C. J. Backhouse, Univ. of Alberta (Canada) 
7187 OK A Monte Carlo study of Mueller matrix decomposition in complex tissue-like turbid media [7187-19]

N. Ghosh, M. F. G. Wood, I. A. Vitkin, Ontario Cancer Institute, Univ. of Toronto (Canada)

IN VITRO

$7187 \mathrm{OL} \quad \mathrm{T}$-matrix based inverse light scattering analysis using angle resolved low coherence interferometry [7187-20]

M. Giacomelli, K. Chalut, J. Ostrander, A. Wax, Duke Univ. (United States)

7187 OM Wavelength-dependent backscattering measurements for quantitative real-time detection of apoptosis in living cells [7187-21]

C. S. Mulvey, C. A. Sherwood, I. J. Bigio, Boston Univ. (United States)

\section{ANIMAL STUDIES}

7187 OS In vivo measurements of epidermal thickness by reflectance mode confocal microscopy to assess cellular proliferation induced by topical agents [7187-27]

K. G. Phillips, R. Samatham, P. Thuillier, S. L. Jacques, Oregon Health \& Science Univ. (United States)

7187 ОT Detecting neoplastic development in the hamster cheek pouch using Fourier domain low coherence interferometry (Invited Paper) [7187-28]

R. N. Graf, F. Robles, Duke Univ. (United States); X. Chen, North Carolina Central Univ. (United States); A. Wax, Duke Univ. (United States)

7187 OU In vivo transcranial measurement of light scattering in rat brains during hypoxia [7187-29] S. Kawauchi, S. Sato, Y. Uozumi, H. Nawashiro, M. Ishihara, M. Kikuchi, National Defense Medical College (Japan)

\section{CLINICAL AND PRECLINICAL STUDIES}

$7187 \mathrm{OW} \quad$ Optimizing Fourier-domain angle resolved low coherence interferometry for clinical use [7187-31]

N. G. Terry, Y. Zhu, M. Rinehart, A. Wax, Duke Univ. (United States)

7187 OY Quantitative optical imaging of early cervical cancer: mechanisms, methods, and clinical study (Invited Paper) [7187-33]

T. T. Wu, Hong Kong Univ. of Science and Technology (Hong Kong, China); T.-H. Cheung, S.-F. Yim, Chinese Univ. of Hong Kong (Hong Kong, China); J. Y. Qu, Hong Kong Univ. of Science and Technology (Hong Kong, China) 
718710 A multi-spectral dark-field reflectance microscope for tumor margin delineation during breast lumpectomy [7187-35]

V. Krishnaswamy, Dartmouth College (United States); W. A. Wells, Dartmouth-Hitchcock Medical Ctr. (United States); A. M. Laughney, K. S. Samkoe, B. W. Pogue, Dartmouth College (United States)

718711 Determine scattering coefficient and anisotropy of scattering of tissue phantoms using reflectance-mode confocal microscopy [7187-36]

R. Samatham, S. L. Jacques, Oregon Health \& Science Univ. (United States)

\section{POSTER SESSION}

718717 Automated segmentation based upon remitted scatter spectra from pathologically distinct tumor regions [7187-42]

P. B. Garcia-Allende, Univ. de Cantabria (Spain); V. Krishnaswamy, K. S. Samkoe, Dartmouth College (United States); P. J. Hoopes, B. W. Pogue, Dartmouth College (United States) and Dartmouth Medical School (United States); O. M. Conde, J. M. Lopez-Higuera, Univ. de Cantabria (Spain)

718718 Identification of the optimal wavelengths in optical topography using photon density measurement functions [7187-43]

T. Correia, A. Gibson, J. Hebden, Univ. College London (United Kingdom)

718719 Light scattering by ellipsoidal particles and Fourier analysis in the frequency domain [7187-45]

K. A. Popov, T. P. Kurzweg, Drexel Univ. (United States)

7187 1A Polarimetric scattering by a bio-medium with anisotropic biomolecules [7187-46]

T.-W. Nee, S.-M. F. Nee, National Yang-Ming Univ. (Taiwan)

7187 1C Extracting optical properties from diffuse optical spectroscopy [7187-48]

R. Nachabé, R. Harbers, A. E. Desjardins, M. van der Voort, G. A. L. Braun, B. H. W. Hendriks, Philips Research (Netherlands)

7187 ID First derivative of NIR light diffuse reflectance spectra as an approach to analyze muscle tissue chromophores and light pathlength [7187-49]

E. Gussakovsky, National Research Council Canada (Canada)

$7187 \mathrm{IE}$ Measurement of subcellular morphology by light scatter filtering with a digital micromirror device [7187-55]

R. M. Pasternack, Z. Qian, J.-Y. Zheng, N. N. Boustany, Rutgers Univ. (United States)

Author Index 
Downloaded From: https://www.spiedigitallibrary.org/conference-proceedings-of-spie on 26 Apr 2023

Terms of Use: https://www.spiedigitallibrary.org/terms-of-use 


\title{
Conference Committee
}

\author{
Symposium Chairs \\ James G. Fujimoto, Massachusetts Institute of Technology (United \\ States) \\ R. Rox Anderson, Wellman Center for Photomedicine, Massachusetts \\ General Hospital (United States) and Harvard School of Medicine \\ (United States)
}

Program Track Chairs

Ammasi Periasamy, University of Virginia (United States)

Daniel Farkas, Cedars-Sinai Medical Center (United Kingdom)

\section{Conference Chairs}

Adam Wax, Duke University (United States)

Vadim Backman, Northwestern University (United States)

\section{Program Committee}

Irving J. Bigio, Boston University (United States)

Stephen A. Boppart, University of Illinois at Urbana-Champaign (United States)

Bernard Choi, Beckman Laser Institute, University of California, Irvine (United States)

Steven L. Jacques, Oregon Health \& Science University (United States)

Lev T. Perelman, Harvard Medical School (United States)

Brian W. Pogue, Dartmouth College (United States)

Bruce J. Tromberg, Beckman Laser Institute and Medical Clinic (United States)

Session Chairs

1 Tissue Phantom Studies

Adam Wax, Duke University (United States)

2 Turbidity Suppression

Adam Wax, Duke University (United States)

3 Dynamic Scattering

Bernard Choi, University of California, Irvine (United States) 
$4 \quad$ Laser Speckle Imaging

Bernard Choi, University of California, Irvine (United States)

$5 \quad$ Numerical Simulation Studies

Vadim Backman, Northwestern University (United States)

$6 \quad$ In Vitro

Vadim Backman, Northwestern University (United States)

$7 \quad$ Animal Studies

Adam P. Wax, Duke University (United States)

$8 \quad$ Clinical and Preclinical Studies

Irving J. Bigio, Boston University (United States)

9 Novel Microscopy

Lev T. Perelman, Harvard Medical School (United States) 